\title{
Biorefinery in Brazil: New Technological Trends Adopted by Domestic Companies
}

\author{
Márcia França Ribeiro Fernandes dos Santos', Suzana Borschiver, \\ Maria Antonieta Peixoto Gomes Couto
}

\begin{abstract}
This article presents the new technological trends adopted by companies based in Brazil on the subject biorefinery that turns out to be a new way to produce chemicals and fuels in a similar way to oil refineries. The survey of information available in literature was obtained through a literature and documents. The results suggest that domestic firms are investing in new technology, especially from sugarcane, taking advantage of long experience in research, development and innovation in farming techniques acquired by tropical country.
\end{abstract}

Keywords: abbreviations; past tense; comprehensive summary; notice; single paragraph.

\footnotetext{
' Escola de Química da Universidade Federal do Rio de Janeiro (UFRJ). Cidade Universitária. Centro de Tecnologia, Bloco E. $2^{\circ}$ nadir. DPO. Área de Gestão e Inovação Tecnológica. Rio de Janeiro, RJ. CEP: 21949-900. Email: marciafribeiro@yahoo.com.br; suzana@eq.com.br; gimenes@eq.com.br
} 


\section{Introduction}

Currently, the Chemistry and Chemical Technology are one of the pillars of modern civilization, because they meet many of the vital needs of society and offer numerous benefits to humanity. However, to fulfill this role, it is vitally important that they develop in a safe, useful and enjoy the confidence of the people.

This idea meets the so called sustainable development paradigm, which is defined in the Brundtland Report (IBGE, 2004), as one that meets the needs of the present time without compromising future generations needs.

International agencies have sought to adopt the guidelines of this new paradigm of development in the formulation of their institutional policies. As example of these policies it would cite the set of objectives to develop and eradicate poverty in the developed world by the United Nations (UN) - the Millennium Development Goals, aimed at their Section 7 ensuring environmental sustainability.

Some measures to achieve this objective are: to ensure the effective conservation and management to reverse the loss of natural resources and significantly reduce biodiversity loss; to introduce innovative financial mechanisms in order to increase significantly the management of the environment; and to promote technological adaptations to mitigate global warming (UN, 2008).

This favors the emergence of Green Chemistry that refers to the practice of chemistry with goals of protecting the environment and health of the biosphere, including humans (Machado, 2004). It may contribute to building a sustainable society and provide a basis to work towards a sustainable future.

Thus, it is necessary that all professionals in the chemical segment engage in the green movement. Examples of sustainable practices in this industry segment are: (i) manufacturing and marketing products that are not harmful to the environment and health of living beings, (ii) use of clean technologies which do not produce toxic waste, (iii) use of materials from renewable natural resources, (iv) use of renewable energy, etc.
These last two aspects are motivating factors for the spread of the idea of sustainability in the Chemical Industry that is based on the binomial matter and energy. According Borschiver (2006) the Organization for Economic Cooperation and Development (OECD) has sought to spread the idea of a sustainable chemistry, based on renewable raw materials and more efficient energy-saving.

Efforts in technological research are being made worldwide for the use of biomass for energy, especially its use in the generation of fuels. In the scenario of developed economies, Brazil stands out for having a clean energy matrix with a high share of renewable sources according to the Brazilian Ministry of Mines and Energy (MME, 2009) the percentage of renewable energy in Brazil is $44.9 \%$ against $13.2 \%$ of the world.

This outlook is due to some comparative advantages such as: Brazil has a watershed of several rivers plateau, fundamental to the production of electricity, it is the largest tropical country in the world, positive differential for the production of biomass energy, thus promoting production of biofuels.

In addition, Brazil is the leader in the generation and deployment of modern technology in tropical agriculture where, over the years, accumulated a vast store of knowledge and a wealth of experience in research, development, innovation management and science and technology. This is evidenced by the production of ethanol, which is considered the world's most efficient in terms of process technology and management, the result of a pioneering program - PROALCOOL - implemented in the 70's.

A new opportunity that is emerging in Brazil is the recovery of waste generated by the production of ethanol from sugarcane as raw material to be used in a wide range of products through integrated and interdependent processes. Thus, the sugar and ethanol mills configure themselves increasingly in the context of so-called biorefineries, which mimic the existing refineries in the oil industry, but on a new basis, renewable and environmentally healthy. Additionally, the industrial biorefineries identify promising routes with a view to creating an economy based on products manufactured from renewable resources. 


\section{Biorefinery}

Jong et al (2005) conceptualized biorefinery as "a facility that integrates the processes of biomass conversion and equipment for the coproduction of fuels, chemicals and energy from various biomass sources".

Pereira Junior et al (2008) states that biorefinery refers to the use of renewable raw materials (biomasses) and their residues, in a most integral and diversified way for the production, by chemical or biotechnological route, a variety of valuable substances and energy with minimal generation of wastes and emissions.

According to Fernando et al (2006) the concept of producing products from agricultural commodities, such as biomass, is not new, however, the use of biomass as a feedstock in the production of various products in a manner similar to an oil refinery where fossil fuels are used as input is relatively new. Its main objective is to transform organic materials into usable products processing industries using a combination of technologies and processes biotechonologies.

The biorefinery concept is analogous to today's petroleum refineries, which produce multiple products, such as fuel and products from petroleum, and where an industrial segment works as a generating pole of raw materials to others.

Kamm et al and Van Dyne et al (apud Fernando et al, 2006) and Halasz et al (2009) suggest the existence of three types of biorefineries that are still in the research and development phase:

(i) the whole crop biorefinery: process and consume the whole grain to obtain the desired product. The process of converting biomass and energy is initiated by mechanical separation of biomass into different components which are treated separately. As an example, it can be mentioned the production of ethanol from corn;

(ii) the green biorefinery: green is a concept that uses biomass (eg, green plants and grains) to produce industrial chemicals (such as lactic acid and amino acids), fine chemicals, fiber and energy from the generation of biogas; and (iii) the lignocellulosic feedstock biorefinery: it will most probably be pushed through with highest success because uses a mix of renewable biomass for a range of products through a combination of technologies, being composed of three basic chemical fractions - hemicellulose, cellulose and lignin.

\section{Methodology}

This work is part of a doctoral thesis in progress that aims to present the new technological trends adopted by domestic companies on the issue biorefinery, seeking to identify information from technical and commercial. The methodology adopted in this exploratory study was based on a literature and documents from a survey of information available in literature. To achieve the goal, information is presented to companies in selected, highlighting key initiatives and technological research and patent protection with a view to commercial use of products produced from biomass, as well as information about projects for biorefinery facilities in Brazil.

\section{Results}

\section{Braskem}

Braskem is one of the three largest Brazilian industries to private capital. The latest example of investment in research and development related to biorefinery was the invention of the $100 \%$ green. This technological innovation as well as absorb carbon dioxide (CO2) from the atmosphere, yet reduces the dependence on raw materials of fossil origin to manufacture of plastic products (Braskem, 2008).

The biopolymers, also known as green polymers, are produced from the ethanol from sugarcane, which, through its own technology, produces ethylene and polyethylene. As these polymers are similar to those produced from oil, the biopolymers are not biodegradable, but on the other hand, they are fully recyclable mechanically - through conversion of plastics into granules that can be used to produce other products - or energy - through the combustion of plastic wastes for energy.

To strengthen its pioneering development of green polymers, Braskem announced in June 2009, an additional 
investment of $\mathrm{R} \$ 8.25$ million to expand research into green propane to produce $100 \%$ renewable polypropylene. The investment is planned for implementation over the next five years through the Foundation for Research of the State of Sao Paulo (FAPESP), which owns $50 \%$ of the project. Braskem is already acting in the pursuit of detail necessary to achieve commercial scale.

As examples of Braskem's new technologies related to biorefinery and protected by patents it can be cited (INPI, 2009): (i) The patent BR 0505093-6 entitled "Process for preparation of composite of cellulosic fibers and polyvinyl chloride, and the resulting composite" (ii) the patent BR 0604284-8 entitled "Integrated process for the production of propylene from natural raw materials and energy, propylene and polypropylene," and (iii) The patent BR 0605I73-I entitled "Process for producing a or more olefins, olefin, and polymer".

\section{Copesul}

Copesul, a Braskem's group company and the largest petrochemical industry in South Brazil, is aligned with the global trend of adding renewable raw material to its product line through the production of ETBE (Ethyl tertiary-butyl ether), a gasoline bioadditive made based ethanol from sugarcane, to replace MTBE (Methyl tertiarybutyl ether), produced with methanol derived from natural gas (Revista Fator Brasil, 2008).

The two additives are designed to increase the octane level, improving the conditions of burning fuel and the quality of atmospheric emissions. However, the main advantages to the use of ETBE can be cited: (i) ETBE is produced from renewable fuel, considering that ethanol is obtained to sugarcane, and (ii) the ETBE has a higher exports compared with MTBE - according to Copesul's data ETBE represents a higher value on the order of US\$ 200 to US $\$ 250$ a ton on MTBE (Protefer, 2008). In view of this, the COPESUL converted his old unit from MTBE to ETBE production.

ETBE is produced by COPESUL since September 2007, using isobutene as raw material, which is a result of the current petrochemical process, and the Brazilian ethanol, produced in Sao Paulo, from sugarcane, so it can be seen as a bioadditive semi-renewable.

\section{Dow Chemical}

\section{Polyethylene from Ehtanol Obtained to Sugarcane}

The Dow, the largest manufacturer of polyethylene in the world, adopted a strategy of diversifying its sources of raw materials to reduce their dependence on those fossil fuels, such as naphtha and natural gas, the usual routes to production of polyethylene (Valor Econômico, 2007).

Consequently, the company decided to invest in sugar cane in Brazil as an alternative and renewable raw materials to fuel its future production of plastic resins. For this venture Dow has partnered with Crystalsev, one of the largest sugar and ethanol mills in Brazil, to build the first integrated Brazilian ethanol hub in the world for the production of green plastic in 201 I. The pole should be established near the plants Crystalsev to take advantage of existing infrastructure, such as logistics and land.

This project involves the construction of an ethanol plant, with capacity to process eight million tonnes of sugarcane per year, switched to a new polyethylene plant that can produce 350 thousand tons of the resin used in packaging and films plastics. Crystalsev provide $\mathbf{7 0 0}$ million liters of ethanol, which will be converted into ethanol and will be converted to ethylene and then transformed into 350 million tons of polyethylene [14]. The technology to produce plastic from sugarcane has been used in the past in Brazil by Union Carbide, now part of Dow in 2000.

\section{Biopolyols Improved from Soybean Oil}

In the early 90's, the Dow began to develop the technology for production of natural biopolyols, according to the company's strategy to reduce dependence on raw materials from petroleum. The production aims to provide performance benefits in a wide range of applications in markets such as furniture, automotive, carpet and coatings, adhesives, sealants and elastomers (Ecoproducers, 2008).

Such technology is greenhouse gas neutral and uses up to $60 \%$ less fossil resources compared to conventional technology for the manufacture of polyols. Polyols produced by Dow are designed to not have the characteristic odor of previous generations of biopolyols an obstacle to their acceptance in commercial terms. The biopoliol produced, in which the molecule functionalized soybean oil and broken reacts with the traditional 
components of polyurethane polyols creates natural oilbased with consistent performance.

The patent BR 040 I I37-4 entitled "Lining of polyurethane carpet, high-performance polyols containing vegetable oils modified" presents an application of biopolyol produced by DOW (INPI, 2009).

\section{Rhodia}

In Brazil, Rhodia has two main production routes: one from the petroleum and another from ethanol via sugarcane. In an attempt to reduce dependence on the petrochemical route, Rhodia follows up the manufacture of products on ethanol - the alcohol from sugarcane is used for the production of solvents such as ethyl acetate and butyl acetate used in the production of paints - so-called green solvents that are products of renewable and considered friendly to the environment and human health (Revista Química e Derivados, 2008). Currently about 15\% to $20 \%$ of the total company in the country is made from this biofuel.

The patent BR 00III69-4 entitled "How to separate lignocellulose containing biomass" refers to a process for separating biomass containing lignocellulose particularly in wood essential components in the form of lignin hemicellulose and cellulose (INPI, 2009).

\section{Oxiteno}

The company presented a project to develop a biorefinery for production of products from sugarcane to the National Bank of Economic and Social Development (BNDES), with a view to its funding in the new lines to support innovation (Inovação UNICAMP, 2006).

The biorefinery will produce sugar and alcohol from raw materials today rejected as bagasse, straw and tips from sugarcane through a technology called acid hydrolysis. The future plant will also produce ethylene and propylene, produced by Oxiteno, by hydrogenolysis, a technology that uses hydrogen to break down sugar (Oxiteno, 2008).

However, the Oxiteno's biorefinery only come to full operation as planned, if they resolved the technological gaps that still hinder the commercial viability of technologies for hydrolysis and hydrogenolysis.
The work in research and development pertaining to the biorefinery by Oxiteno reached the U.S. patent application 0500534-5 entitled "Process for the acid hydrolysis of cellulosic and lignocellulosic materials, vessel digestion and hydrolysis reactor (INPI, 2009).

\section{Petrobras}

\section{Bioethanol Lignocellulose}

With the development project of bioethanol (cellulosic ethanol) - a biofuel produced from agroindustrial residues Petrobras enters the production of second generation biofuels in biofuels (Petrobras, 2008).

After the stage of laboratory tests, the design of bioethanol production is to be tested on a pilot scale, using an experimental unit installed in the Research Center of Petrobras (CENPES). The pilot plant for ethanol from lignocellulose is unique in Brazil using enzyme technology. For the production of ethanol from agroindustrial residues, the plant uses a process of breaking down the action of enzymes. The project was developed by Petrobras in partnership with the Federal University of Rio de Janeiro (UFRJ) and other universities.

Any reject can be used as a source of biomass in experimental plant, but the system is set to bagasse of sugarcane, being the most significant agricultural residue in the country. Another raw material that will be used in the tests is the castor bean, starch residue from the production process of biodiesel from castor beans.

The experimental plant is capable of producing about 220 liters of ethanol per ton of sugarcane's bagasse. At this stage of the research project, researchers working on the optimization of production process and aims to reach the mark of 280 liters per ton of bagasse the same equipment.

Petrobras forecasts that in 2010 it built a semi-industrial plant of bioethanol. Examples of new technologies related to the Petrobras biorefinery and protected by patents are cited (INPI, 2009): (i) The patent BR 06050I7-4 entitled "Process for the production of ethanol from lignocellulosic materials by enzymatic" and (ii) The patent BR 0505299-8 entitled "Process for the production of ethanol from the hemicellulose hydrolysates of sugarcane bagasse, sugartype reactor in press. 


\section{Nova Petroquimica}

The company develops alternative production of polypropylene resin obtained so far of oil from the glycerin is left as a byproduct of biodiesel development (Oliveira, 2008).

A pilot plant has been operating since 2009 in the town of Maua, Greater Sao Paulo, for an assessment of the processes and initiated a small-scale production by $20 \mathrm{II}$. This pilot plant will give the dimensions for the final plan, which should have an initial production of 100 thousand tons/year of green resin.

The total industrial investments should reach US $\$ 50$ million. The route the company's production follows other large manufacturers of raw materials for the production of plastics, as Braskem, Dow Chemical and Oxiteno, companies with projects for the production of polymers of plant origin using mainly sugar from sugarcane. Along with the glycerin from the biodiesel they are forming a green or renewable petrochemical chain.

The Brazilian legal permission to add 5\% biodiesel in petroleum diesel (B5) entered into force in January Ist 2010 , in advance, so in 3 years, since in accordance with the provisions of Law II,097 of January 2005 which regulates the National Program of Biodiesel (PNPB), this percentage would come into force only in 2013. Thus, it is estimated that the surplus of glycerol will be 250 tons. The problem is that the Brazilian market consumes only 40 tons of glycerin per year.

Therefore it is necessary to study new ways to use this product beyond the usual as in cosmetics, the composition of capsules, syrups, creams, paints, varnishes and detergents, preservation of food, beverage and packaging.

\section{Conclusion}

The study shows that companies based in Brazil has invested in projects to increase the use of renewable raw materials, especially for production of ethanol from sugarcane, to reduce dependence on oil considering the instability of price of this commodity in the international market during 2008.

Additionally, given the pressures surrounding the developed countries on the increase of food prices due to biofuels, a new opportunity for the Chemical Industry has delineated - the use of agroindustrial residues, especially bioethanol's production from lignocellulose and glycerin as a byproduct of biodiesel production.

In this context, the concept of integrated biorefineries for production of chemicals and fuels have been consolidated worldwide face the pressures of an environmental nature and social-economic development. Although there are still barriers to technical and economical for the commercial development of this new technology, the focus of most research seems to indicate that the deployment of biorefineries is a path to be adopted in response to such pressures.

It should be noted that projects involving biorefineries have been shown to be viable alternatives in terms of environmental, considering the production is less harmful products, and companies can make use of such projects to generate carbon credits, thereby obtaining a financial advantage. Thus, this new technology proves to be adhering to the precepts of green chemistry to meeting the guidelines of the sustainable development paradigm.

\section{References}

IBGE (2004) Indicadores de Desenvolvimento Sustentável: Brasil 2004. IBGE, Rio de janeiro, 400 p. Estudos e pesquisa. Informação geográfica, 4.

UN (2008). United Nation Department of Public Information. DPI/25I7 M. September 2008. http://www.un.org/milleniumgoals. [Acessed February 10, 2009]

MACHADO A. A. S. C. (2004). Química e Desenvolvimento Sustentável - QV, QUIVES, QUISUS? http://www.spq.pt/boletim/docs/boletimSPQ_095_059_09. pdf. [Acessed July 12, 2008]

BORSCHIVER S. (2006). Desafios da Sustentabilidade. Revista Brasileira de Engenharia Química. Dezembro, 2006. Pp. 24-25.

MME (2009) Plano Nacional de Energia 2030. http://www.mme.gov.br [Acessed March 3I, 2009]

JONG, E., Ree, R., Tuil, R. F., Elbersen, W., (2005). Biorefineries for the Chemical Industry - A Dutch point of 
view. In: Proceedings of the 2005 annual meeting of the association for the Advancement of Industrial Crops: International Conference on Industrial Crops and Rural Development, 17-2I September 2005, Murcia, Spain.

PEREIRA JUNIOR, N., Couto, M. A. P. G., Santa Anna L. M. M., (2008). Biomass of Lignocelulosic Composition for fuel ethanol production within the context of biorefinery. Rio de Janeiro: Escola de Química/UFRJ, 2008.

FERNANDO S., Adhikari S., Chandrapal C., Murali N., (2006). Biorefineries: Current Status, Challenges and a Future Direction. Energy \& Fuels, 20, I727-1737.

HALASZ L., Povoden G, Narodoslawsky M. (2005). Sustainable processes synthesis for renewable resources. Resources, Concervation and Recycling, 44, pp. 293-307, 2005.

BRASKEM (2008). Inovação e Tecnologia.. http://www.braskem.com.br. [Acessed March 5, 2010]

INPI (2009). Pesquisa na base de patentes. http://www.inpi.gov.br. [Acessed July 7, 2009]

REVISTA FATOR BRASIL (2008). Copesul entra no mercado mundial de biocombustíveis. http://www.revistafatorbrasil.com.br. [Acessed July 25, 2008]

PROTEFER (2008). Tecnologias. http://www.protefer. com.br. [Acessed July I8, 2008]

VALOR ECONÔMICO (2007). Dow Chemical anuncia intenção de fabricar plásticos no Brasil a partir de cana-deaçúcar; planta começaria a funcionar em $201 \mathrm{l}$. http://www.valoreconomico.com.br. [Acessed July 19, 2007]

ECOPRODUCERS (2008). Dow Poliuretanos lança produto sustentável. http://www.ecoproducers.com/ magazine/index.php?option=com content\&task=view\&id=I 95\&ltemid $=164$. [Acessed July 07, 2008]

REVISTA QUIMICA E DERIVADOS (2008). Atualidades. http://www.quimicaederivados.com.br/revista/qd437/atualid ades I.htm. [Acessed July 03, 2008]
INOVAÇAO UNICAMP (2006). Boletim dedicado a inovação. http://www.inovacao.unicamp.br/report/entrecarloscalmanovice.shtml. [Acessed September 18, 2006

OXITENO (2008). Oxiteno apresenta projeto ao BNDES para construir biorrefinaria. http://www.oxiteno.com.br. [Acessed July 06, 2008]

PETROBRAS (2008). Energia e Tecnologia. http://www.petrobras.com.br. [Acessed July 07, 2008]

OLIVEIRA, M (2008). Petroquímica Verde - Glicerina que sobra da produção de biodiesel será usada para produzir polipropileno. Edição Impressa I49, Julho. 